\title{
26. PLIOCENE TO HOLOCENE STRUCTURE OF THE EASTERN ALBORAN SEA (WESTERN MEDITERRANEAN) ${ }^{1}$
}

\author{
J. Alvarez-Marrón²
}

\begin{abstract}
Since the early Pliocene, the active tectonic setting of the Eastern Alboran Sea has been characterized by active strike-slip tectonism, causing the main bathymetric depressions to form in the eastern part of the Alboran Sea, the Eastern Alboran Basin, the Yusuf Basin, the Alboran Channel, and the South Alboran Basin. The Eastern Alboran Basin is a 2000-m-deep, mostly flatbottomed, triangular-shaped graben developed between the Iberian and African continental margins. Ocean Drilling Program (ODP) Leg 161 data provide the time frame for the late Miocene to Holocene history of the basin. At Site 977, $600 \mathrm{~m}$ of Miocene(?)-Pliocene to Holocene marine sediments were drilled, and $700 \mathrm{~m}$ of upper Miocene to Pleistocene marine sediments at Site 978 . Within the sedimentary package, several unconformities reveal the active strike-slip tectonism that occurred during this time.

At the southern border of the Eastern Alboran Basin the active, right lateral strike-slip Yusuf Fault is developing. Reflection seismic profiling shows that, at a right stepover of the Yusuf Fault, a developing negative flower structure is causing the Yusuf Basin to form, in which active tectonic subsidence has been ongoing since at least the late Miocene. Above the interpreted Messinian reflections, the sedimentary fill forms a northeastward-thickening wedge of syntectonic sediments of Pliocene to Holocene age.

In the South Alboran Basin, drilling at Site 979 penetrated Pliocene to Holocene syntectonic sediments, which form growth strata geometries related to a south-dipping monocline that evolved above a north-dipping thrust fault in the basement. North of the Alboran Ridge, a narrow strike-slip basin is forming in the Alboran Channel next to the strike-slip fault at the northern flank of the ridge.
\end{abstract}

\section{INTRODUCTION}

The Betic-Rif orogen, located at the westernmost end of the Mediterranean (Fig. 1), evolved from Paleogene to Holocene times at the boundary between the Eurasian and African plates (Olivet et al., 1984; Dewey et al., 1989; Srivastava et al., 1990). Within the internal areas of the orogen, and surrounded by its contractional arcuate orogenic front, extensional processes resulted in the formation of the Alboran Basin during the Neogene (Comas et al., 1992; Watts et al, 1993). Since the late Tortonian, the dominant tectonic regime has been mainly strike-slip (Comas et al., 1992; Bourgois et al., 1992; Woodside and Maldonado, 1992), while active convergence between Africa and Iberia was still occurring (Dewey et al., 1989). Strike-slip tectonics is thought to have played a significant role in the present morphology of the Alboran Basin (Comas et al., 1997), and active right lateral transpression related to oblique convergence between the African and Iberian plates continues to influence the development of the Alboran area (Argus et al., 1989; DeMets et al., 1990; Albarello et al, 1995; Morel and Meghraoui, 1996).

The determination of the tectonic evolution of the Alboran Basin has been the focus of much research in the past decades (Pastouret et al., 1975; Auzende et al., 1975; Dillon et al., 1980; Kazakov et al., 1983; Gensous et al., 1986; Watts et al., 1993; Comas et al., 1997). Seismic surveying and borehole data acquired by the oil industry have been largely confined to the margins of Spain and Morocco. Little attention has been paid to the recent structure of the eastern part of the Alboran Sea. Ocean Drilling Program (ODP) Leg 161 has recently drilled three sites in the central and eastern areas of the Alboran Sea (Comas, Zahn, Klaus, et al., 1996), which provide new data that

'Zahn, R., Comas, M.C., and Klaus, A. (Eds.), 1999. Proc. ODP, Sci. Results, 161: College Station, TX (Ocean Drilling Program).

${ }^{2}$ Instituto Andaluz de Ciencias de la Tierra, CSIC-Universidad de Granada, 18002 Granada, Spain. (Present address: Instituto de Ciencias de la Tierra, Consejo Superior de Investigaciones Científicas, 08028 Barcelona, Spain.) jalvarez@ija.csic.es help to constrain the Pliocene to Holocene tectonic history of the area. This paper analyzes the structure of the eastern part of the Alboran Basin (east of $3.5^{\circ} \mathrm{W}$ ), integrating Leg 161 borehole data (Sites 977, 978, and 979) and interpretation of reflection seismic profiles. The seismic profiles used in this paper include the new 77-km-long profile (Line S3) acquired by the JOIDES Resolution (Klaus and Shipboard Scientific Party, 1996), available seismic data acquired by the Lamont-Doherty-operated vessel Robert D. Conrad (for information on acquisition and processing see Watts et al., 1993) and the Ray surveys (Fig. 2).

\section{GEOLOGICAL FRAMEWORK}

The Alboran Sea is an east-west elongated, marine basin with water depths that reach $2000 \mathrm{~m}$. It is flanked to the north and south by the narrow shelves and slopes of the Iberian and African land masses. Several sub-basins, ridges and seamounts can be identified. To the east of the Alboran Ridge in particular, the South Alboran, East Alboran and Yusuf Basins are important for this study (Fig. 2). The Alboran Ridge is a linear bathymetric high that extends some $180 \mathrm{~km}$ with a northeast-southwest trend, and is locally emergent forming the volcanic Alboran Island (Figs. 1 and 2). This ridge terminates abruptly to the north against the Alboran Channel, which constitutes a narrow east-west-trending connection between the western and eastern sides of the Alboran basin.

The Alboran Basin appears to be floored predominantly by continental basement that largely corresponds to rocks belonging to the internal complexes of the Betic-Tell orogen (the Alboran Domain; Balanyá and García-Dueñas, 1987). The continental nature of the crust beneath the Alboran Basin is confirmed by drilling results at ODP Site 976 (Comas, Zahn, Klaus, et al., 1996; Platt et al., 1996) that is to the west of the area studied in this paper (Fig. 1). However, most bathymetric highs in the center and eastern parts of the basin (east of $4^{\circ} \mathrm{W}$ ) are of volcanic origin, as revealed by dredging (Gierman et al., 1968) and submersible data (Comas et al., in press). Lower Miocene 

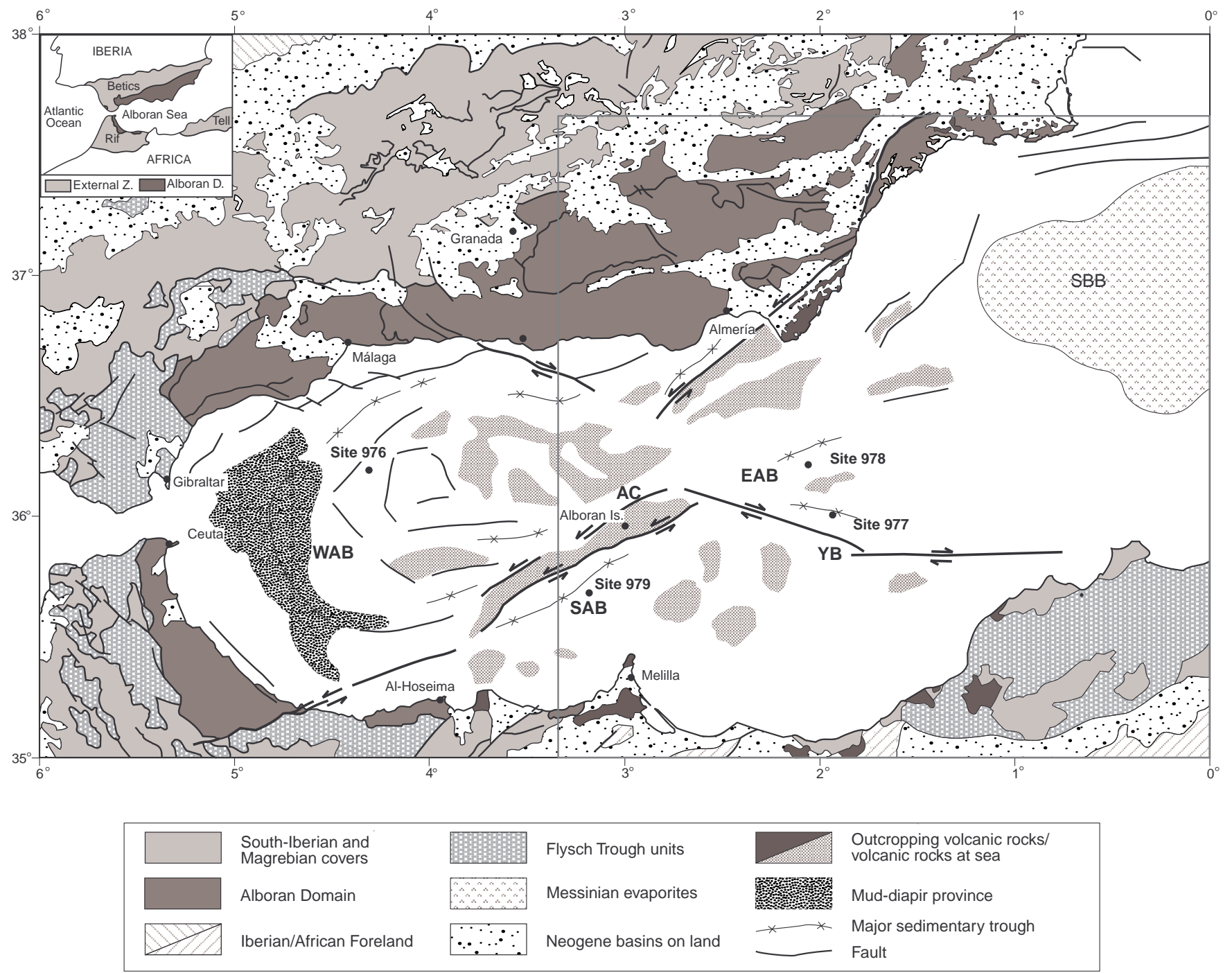

Figure 1. Regional geological sketch map of the Betic-Rif orogen indicating major geological features in the Alboran Basin (simplified from Comas et al., 1997), and location of ODP Leg 161 sites. A conjugate set of strike-slip fault systems marked in black lines crosses the entire basin. EAB = Eastern Alboran Basin; SAB $=$ South Alboran Basin; SBB = South Balearic Basin; WAB = Western Alboran Basin; YB = Yusuf Basin. Box marked with grey line is the area in Figure 2.

and upper Serravallian to Tortonian alkaline and calc-alkaline volcanic rocks (Bellon et al., 1983; Hernández et al., 1987) exposed on shore have also been sampled offshore. Some of these offshore magmatic events have been attributed to the main extensional processes in the basin (Comas et al., 1992). In addition, the youngest volcanism that includes Messinian lamprophyres, shoshonitic lavas (4.5-9 Ma.), and alkali basalts (1.5-6 Ma.) erupted extensively in the basin (Bellon et al., 1983; Hernández et al., 1987; Montenat et al., 1992; de Larouzière et al., 1988).

Refraction/wide-angle seismic and gravity data indicate that an abrupt change in crustal thickness occurs from the Betics $(38 \mathrm{~km})$ to the center of the Alboran Sea (15-20 km; Hatzfeld, 1978; Banda and Ansorge, 1980; Torné and Banda, 1992; Banda et al., 1993; Watts et al., 1993). A pronounced decrease in lithospheric thickness also occurs from the Western Alboran Basin (90-50 km) to the Eastern Alboran Basin (35-40 km), together with an east-west crustal thinning from 14-16 km to 10-12 km, respectively (Polyak et al., 1996).

The seismic configuration of the Alboran Basin sedimentary fill has been analyzed in previous studies (Pastouret et al., 1975; Auzende et al., 1975; Dillon et al. 1980; Kazakov et al., 1983; Gen- sous et al., 1986; Comas et al., 1992; Watts et al., 1993). A general lithostratigraphic column was established from commercial well data along the Iberian Margin (Jurado and Comas, 1992), and it indicates the existence of lower Miocene (Aquitanian(?)-Burdigalian) to Pleistocene sedimentary sequences with common lateral thickness variations. Several unconformities have been recognized within the borehole data and in the seismic profiles (Comas et al., 1992), of which the most prominent is thought to represent a regional event that took place at the base of the Pliocene-Pleistocene sequences, and corresponds to a strong erosional and local angular unconformity that correlates with the top of the Messinian evaporites M-reflector recognized elsewhere in the Mediterranean (Ryan, Hsü, et al., 1973).

\section{Overview of the ODP Stratigraphic Data}

Figure 3 summarizes the stratigraphy sampled at ODP Leg 161, Sites 977, 978 and 979. These sites have been described in detail by Comas, Zahn, Klaus, et al. (1996), and only the features relevant to this paper are shown in Fig. 3 and will be described. Sites 977 and 978 were drilled in the Eastern Alboran Basin, sampling both sides of 


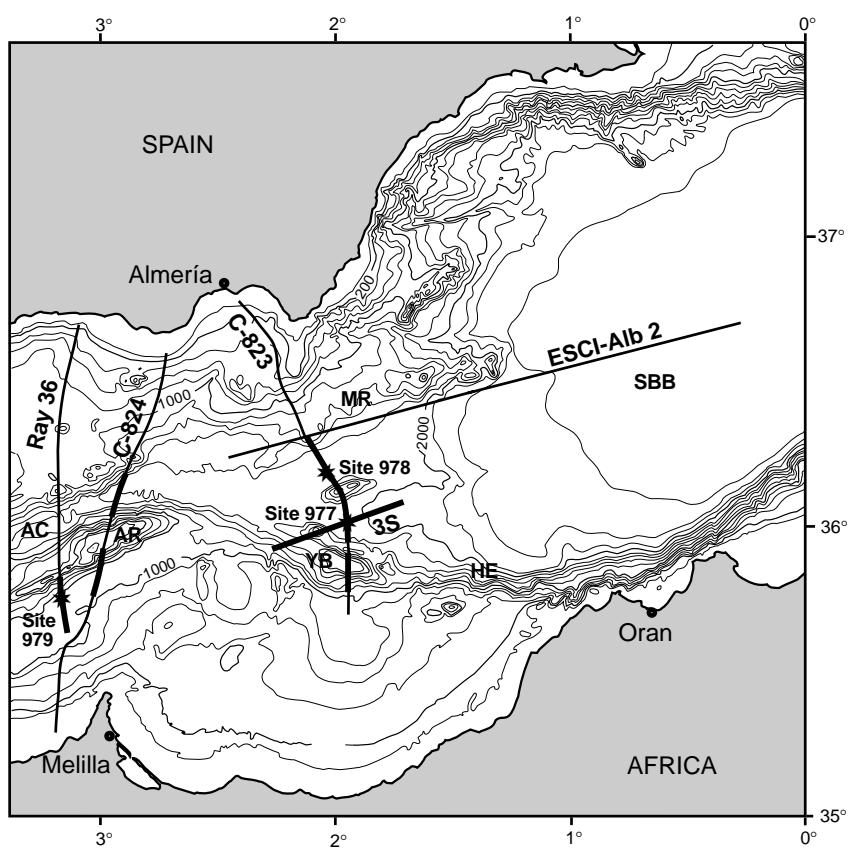

Figure 2. Bathymetric map of the Eastern part of the Alboran Sea showing location of data used for this study (see Fig. 1 for location). Bathymetric data is from the International Bathymetric Chart of the Mediterranean Scale 1:1000000 (IOC-UNESCO, 1981). Thicker lines show the portions of seismic lines shown in following figures. $\mathrm{AC}=$ Alboran Channel; $\mathrm{AR}=$ Alboran Ridge; HE = Habibas Escarpment; $\mathrm{MR}=$ Maimonides Ridge; $\mathrm{SBB}=$ South Balearic Basin; YB = Yusuf Basin.

a prominent volcanic high (Al-Mansour Seamount; Fig. 2). Site 977 sampled $598.5 \mathrm{~m}$ of Miocene(?)-Pliocene to Holocene marine sediments that have been divided in two units. Although the biostratigraphic data are not conclusive as to whether the Miocene/Pleistocene boundary was reached, the existence of Miocene nannofossil marker species in the lowest $533 \mathrm{~m}$ of the section, suggest an uppermost Miocene age. This lowermost unit (Unit II) is composed of partly cemented sandy gravel with predominantly volcanic clasts and rare sedimentary clasts interpreted to correspond with the seismic Mreflector. The Pliocene-Pleistocene section (Unit I) is composed of nannofossil clay to nannofossil-rich silty clay of open-marine, hemipelagic facies turbidites, evidenced by some intervals of slumping. A short depositional hiatus occurs at the base of Subunits IC and IB. Average sedimentation rates were $96 \mathrm{~m} / \mathrm{Ma}$ and $154 \mathrm{~m} / \mathrm{Ma}$ in the Pliocene and Pleistocene sections, respectively.

Site 978 intersected $481.3 \mathrm{~m}$ of upper Miocene (Messinian or uppermost Tortonian age) to Pleistocene marine sediments that were divided into three units (Fig. 3). At the base of the section, Unit III consists of well consolidated upper Miocene sandy and silty layers. Numerous fractures were identified in the cores that, locally, are a breccia. Unit II consists of a gravel-bearing interval containing volcanic, metamorphic, and sedimentary clasts. Unit II is thought to correlate with the erosive surface corresponding to the M-reflector. The lower Pliocene-Pleistocene section (Unit I) is mostly made up of pelagic and hemipelagic sediments with lesser low-density turbidites deposited in open marine conditions. Although the bedding is subhorizontal in most of Unit I, several structures, such as frequent slumping, folding, and faulting, were found near its base. Average sedimentation rates are 120 and $111 \mathrm{~m} / \mathrm{Ma}$ for the early and late Pliocene, respectively.

Site 979 was drilled in the South Alboran Basin, to the southeast of the Alboran Ridge (Fig. 2), penetrating $580.9 \mathrm{~m}$ of upper Pliocene

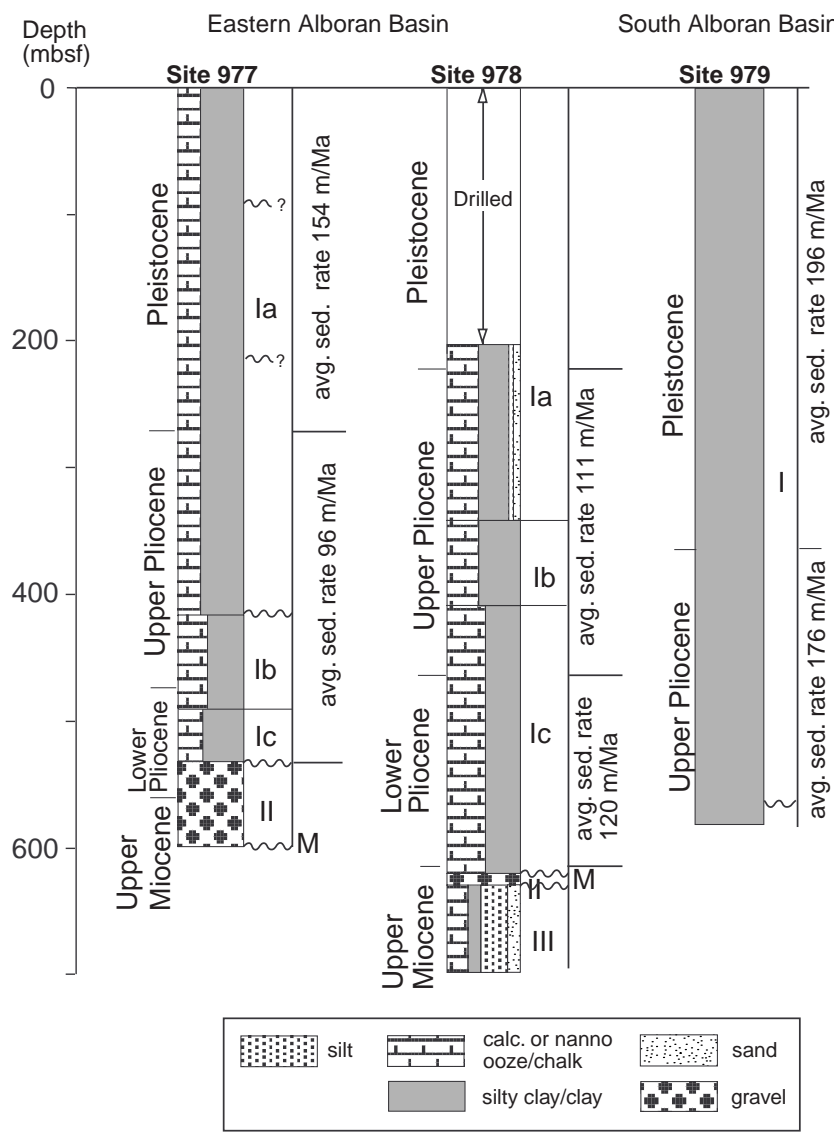

Figure 3. Simplified stratigraphy of Sites 977,978 and 979 indicating the ages of main lithologies drilled (redrafted from Comas, Zahn, Klaus, et al., 1996). Location of drilling sites in Figure 2.

to Pleistocene/Holocene open-marine and hemipelagic deposits with minor siliciclastic detrital layers (Fig. 3), in which one lithologic unit was identified. For the most part, the sediments are horizontal with local intervals of dipping beds, which may have resulted from slumping. Average sedimentation rates are 196 and $176 \mathrm{~m} / \mathrm{m}$.y. for the Pleistocene and late Pliocene, respectively.

\section{STRIKE-SLIP STRUCTURAL STYLES}

The dominant strike-slip faults in the Alboran Basin form a northeast-southwest and west-northwest-east-southeast conjugate system with a $50-60^{\circ}$ acute angle between the two strands (Fig. 1). Northeast-southwest- and northwest- to east-southeast-trending fault systems have left and right lateral sense of movement, respectively. Some of these faults can be traced on shore where they have been studied in detail. On the Iberian side, the northeast-southwest left lateral Carboneras fault system shows a minimum displacement of 25 $\mathrm{km}$ (Keller et al., 1995), belonging to a left lateral strike-slip fault system in the Almería area (Montenat, 1990). Minor northwestsoutheast striking right lateral faults to the east of Málaga have been interpreted as the conjugate system to the Almería fault system (García-Dueñas et al., 1992; Balanyá, 1991). Northeast-southweststriking faults in the Rif orogen of Morocco have a left lateral sense of movement. West-northwest- to east-southeast-striking right lateral faults are present in the Tell region (Morel and Meghraoui, 1996; Meghraoui et al., 1996), and the Yusuf Fault in the eastern Alboran Sea (Mauffret et al., 1987, 1992) correspond to this system. Most of 
these faults are presently active within the Ibero-Maghrebian region of distributed seismicity that is presently considered the plate boundary between Eurasia and Africa (e.g., Buforn et al., 1995).

\section{Eastern Alboran Basin}

The Eastern Alboran Basin is a 2000-m-deep, triangular-shaped, flat-bottomed basin that widens eastward from the Alboran Channel in the west to the larger South Balearic Basin in the east (Fig. 2). The northern flank is comprised of the rough, 1000-m-high Iberian slope where the Maimonides Ridge, a prominent volcanic high, forms the northern escarpment of the basin. In the south, the Eastern Alboran Basin is flanked by the steep slope of the Habibas Escarpment, that trends west-northwest-east-southeast until $2^{\circ} \mathrm{W}$ where it changes to a more east-west orientation. The change in the trend coincides with the appearance of the narrow Yusuf Ridge. A southwest-northwest elongate, prominent volcanic high, the Al-Mansour Seamount, occupies the central part of the Eastern Alboran Basin, and Sites 977 and 978 were drilled to the south and north of this ridge, respectively (Fig. 2).

Both Sites 977 and 978 reached an upper Miocene unconformity correlated with the M-reflector. The M-reflector is a very prominent feature in the Conrad 823 profile, because it separates two sedimentary sequences above (post-M) and below (pre-M) that exhibit a markedly different reflection character (Fig. 4). The M-reflector can be traced across the whole section of the Eastern Alboran Basin and is considered to represent the base of the Pliocene-Pleistocene sedimentary sequences, a reference boundary for the interpretation of the structure of the Eastern Alboran Basin.

The structure of the Eastern Alboran Basin includes both extensional and compressional faults that converge downward on both sides of Al-Mansour Seamount, and the M-reflector is slightly folded above some of the faults (Fig. 4). However, not all faults seen beneath the M-reflector deform the upper Pliocene to Holocene sedimentary sequence. In particular, the M-reflector is slightly folded in the northern part of the basin, above two major faults, and sediments above the M-reflector are subhorizontal and thicken southward. Only minor normal faults can be identified in this upper sedimentary package. Along the southern side of the Al-Mansour Seamount, an unconformity is seen within the post-M sedimentary package which is thicker at the central part, where Site 977 was drilled. The unconformity, which is folded across an open anticline, is marked by an onlap configuration of reflections above the southern limb of the fold. The post-M sediments also onlap southward onto the Yusuf Ridge and are down-dropped along extensional faults that produce a terraced basin sidewall at the slope of the ridge (Fig. 4).

A northeast-southwest section of the southern part of the Alboran Basin shows the Pliocene-Pleistocene sedimentary sequences onlapping onto the M-reflector at the Yusuf Ridge and thickening toward the northeast (Fig. 5). Above the M-reflector, within the Pliocene to Holocene sedimentary sequences sampled by Site 977 , two unconformities can be determined. The stratigraphically lowest of these is openly folded and is marked by the onlap configuration of reflectors above the southern limb of the fold (Fig. 6). The uppermost of the two unconformities is marked by the truncation of the reflections clearly seen in the steeper side of the antiform, and it is only slightly folded. Northeast of the fold, the unconformities can no longer be identified in the seismic profile. A negative flower structure composed of downward-convergent faults with normal and reverse throws has developed next to a master fault at the southern border of the basin (Fig. 6 ). The configuration of reflections beneath the M-reflector resulted in a morphology that resembles basin inversion structures. The overprinting of extensional faults by the strike-slip structures resulted in a flower structure, where the two bounding strike-slip faults may reactivate previously extensional faults. The upper sequence, above the M-reflector is deformed by an open, asymmetric synsedimentary antiform developed above two convergent upward, reverse faults.

\section{The Yusuf Basin}

The Yusuf Basin is bound to the north by the steep Yusuf Ridge and to the south by the less steep African continental slope. The rhomb-shaped topographical expression of this basin led Mauffret et al. (1987) to consider it as a present-day pull-apart basin developed next to the Yusuf strike-slip fault. The Yusuf fault is the western strand of two right-stepping nonparallel master faults that form the Yusuf right lateral strike-slip fault system. The eastern master fault is located at the east-west-trending Habibas escarpment (Fig. 2). The Yusuf Basin is a good example of an active, marine, strike-slip basin. It forms an elongate trough parallel to the strike of the Yusuf Fault, and occurs at the right stepover between the two nonparallel master faults (Fig. 2). The trough has two morphological parts: the eastern

\section{SSE}

CONRAD 823

NNW

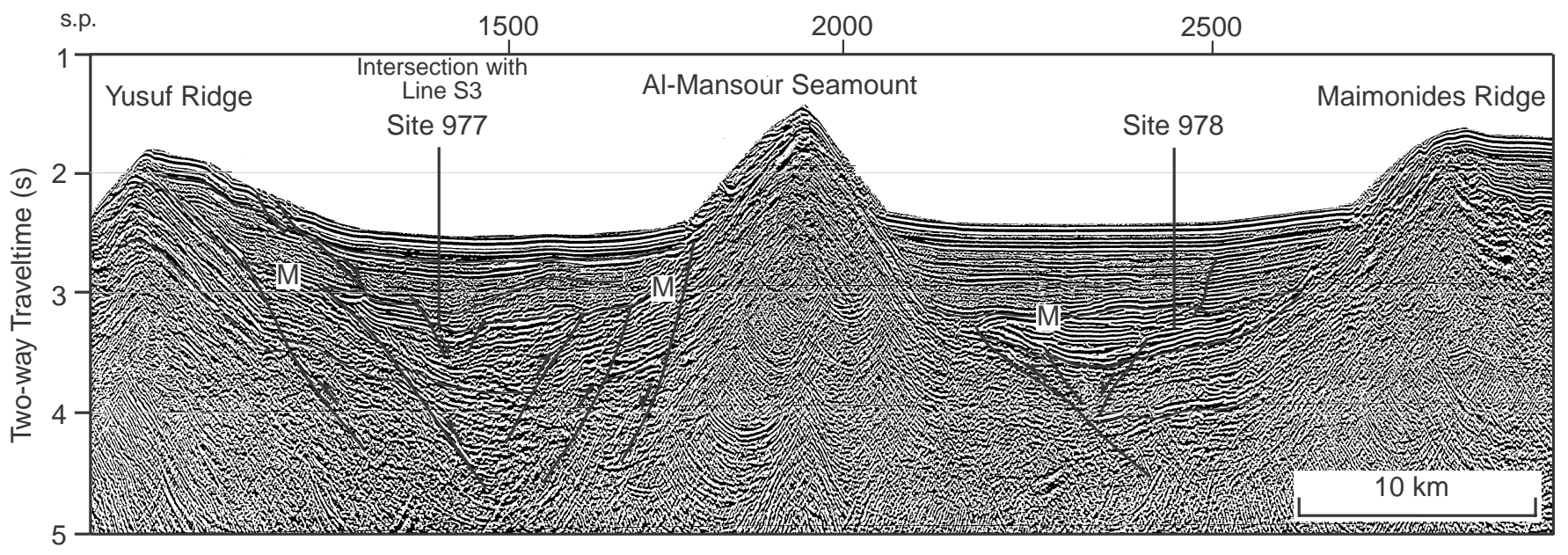

Figure 4. Interpretation of Conrad 823 profile across the Eastern Alboran Basin, showing the two negative flower structures at both sides of the Al-Mansour Seamount. Two markedly different reflective characters of the Upper Miocene to Holocene sediments are separated by the M-reflector (M). Within the PlioceneHolocene sediments, other unconformities form as a result of active tectonics during this time. s.p. = shotpoints. Location in Figure 2. 


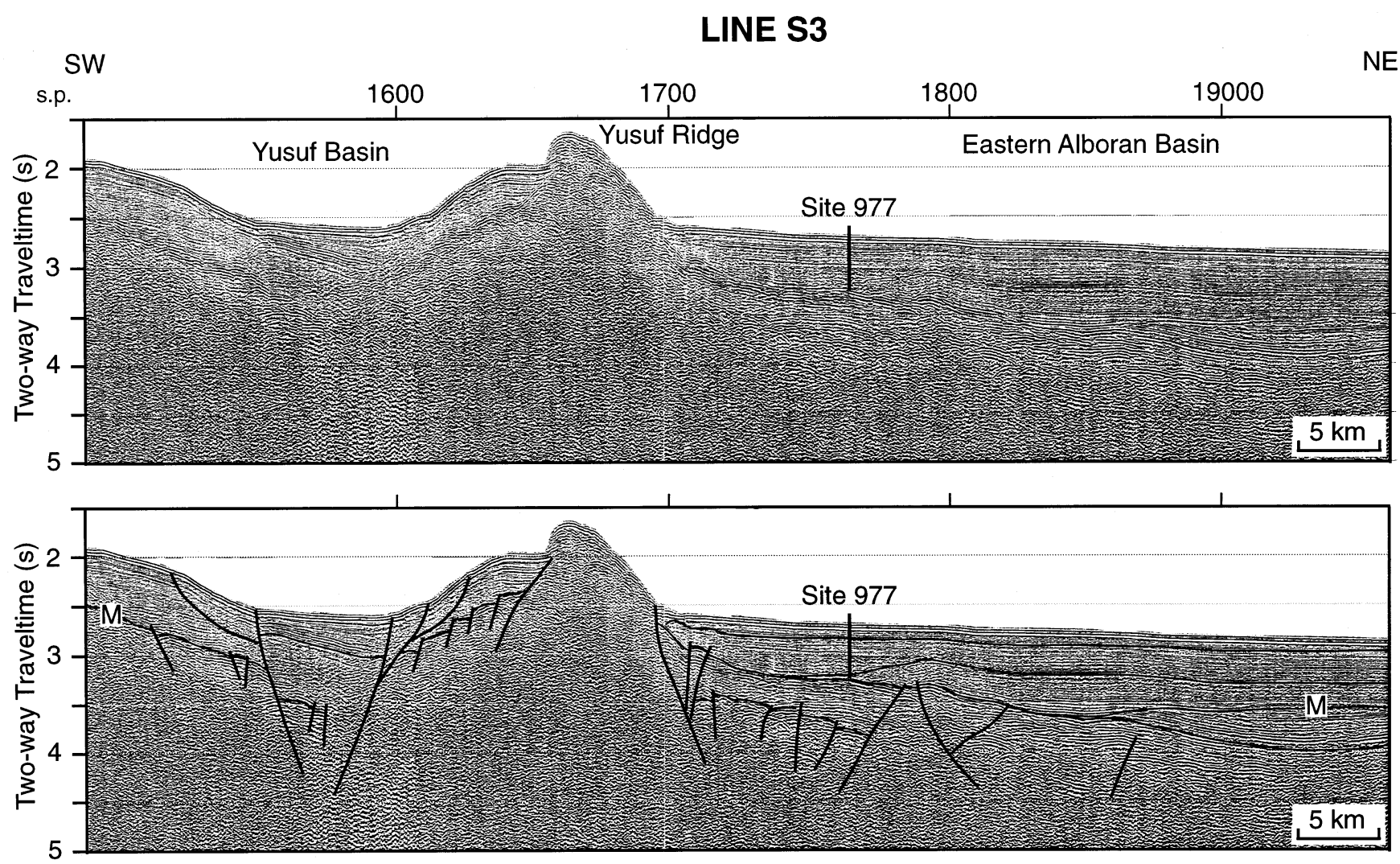

Figure 5. Line 3S (top) and its interpretation (bottom) showing the deepening of the Eastern Alboran Basin toward the East, and strike-slip related structures (see text for explanation). M = M-reflector, s.p. = shotpoints. Location in Figure 2.

part forms a 2330-m-deep, elongate, flat-bottomed graben, measuring $16 \mathrm{~km}$ long by $9 \mathrm{~km}$ wide; the western part is formed by a narrow, very gently east-dipping channel with a deeper incision next to the Yusuf Fault (Fig. 7). The channel that has shallower bathymetry (1900 m deep) connects to the west with the Eastern Alboran Basin and a steep $400 \mathrm{~m}$ high escarpment occurs between the graben and the eastern end of the channel. Along the northern flank of the deep graben, the Yusuf Ridge forms a 900-m-high, steep fault escarpment whose height diminishes and disappears westward next to the channel.

Other right lateral strike-slip faults parallel to the Yusuf Fault have been interpreted to occur at topographic breaks in the southern side of the basin. Two oblique topographic breaks may correspond to synthetic faults between the zone of right lateral strike-slip system (Fig. 7).

Line S3 and Conrad 823 (Watts et al., 1993) seismic profiles image the structure of the Yusuf Basin (Figs. 8, 9). In the west, the basin forms a negative flower structure bound by two master faults, with the Yusuf Fault being the main bounding fault (Fig. 8). The Yusuf Fault exhibits an apparent vertical throw of greater than $2 \mathrm{~km}$ (assuming an average velocity of $2 \mathrm{~km} / \mathrm{s}$ for the sediments). Although the basement cannot be clearly distinguished, $\sim 2000 \mathrm{~m}$ of sedimentary fill is seen between the two bounding faults, and a thinner sedimentary layer covers the slopes of the channel to the west of the main trough. A sharp contrast in the reflectivity pattern within the sedimentary fill can be identified, similar to that observed in the Eastern Alboran Basin. The boundary between the two is interpreted to correspond to the M-reflector, allowing a correlation to be made at both sides of the Yusuf Ridge (Fig. 5). Reflections above the M-reflector form a northeast- or east-thickening fan between the two master faults, which images the youngest syntectonic sediments, probably corresponding to the Pliocene to Holocene sequences. A pre-M sedimentary package imaged by a highly reflective band $150 \mathrm{~ms}$ thick, appears deformed by closely spaced extensional faults, while post-M sediments accommodate the extension by lower angle faults that detach above the M boundary.

In the east, a section nearly perpendicular to the deep graben of the Yusuf Basin, the sedimentary fill is at least $1 \mathrm{~s}$ thick and forms a symmetric synform that progressively disappears upward between two main bounding faults (Fig. 9). An unconformity in the upper part of the basin fill is marked by reflections that appear to onlap onto both limbs of the synform. The steep southern slope of the Yusuf Ridge is hardly covered by sediments in this section, while a thick sedimentary package forms a perched narrow terrace in the southern side. A second terrace in the southern edge of the profile shows a marked unconformity between upper flat-lying sediments and southdipping sediments beneath.

\section{South Alboran Basin and the Alboran Channel}

The South Alboran Basin is a northeast-southwest elongate bathymetric low (about $1000 \mathrm{~m}$ deep) located between the Moroccan margin and the southern slope of the Alboran Ridge. The Alboran Channel appears to the north of the Alboran Ridge, and, in profile Conrad 824 , it is a 6-km-wide asymmetric strike-slip basin filled by subhorizontal sediments that are at least $1.5 \mathrm{~s}$ thick (Fig. 10). The sedimentary fill is bound to the south by a master strike-slip fault and the sediments appear to onlap onto the south-dipping top-basement to the north. Minor fault splays deform the sedimentary fill.

The South Alboran Basin is an asymmetric basin (Watts et al., 1993 ) with a variable sedimentary thickness above a rough basement of probable volcanic origin (Comas et al., 1992). Site 979 was drilled 


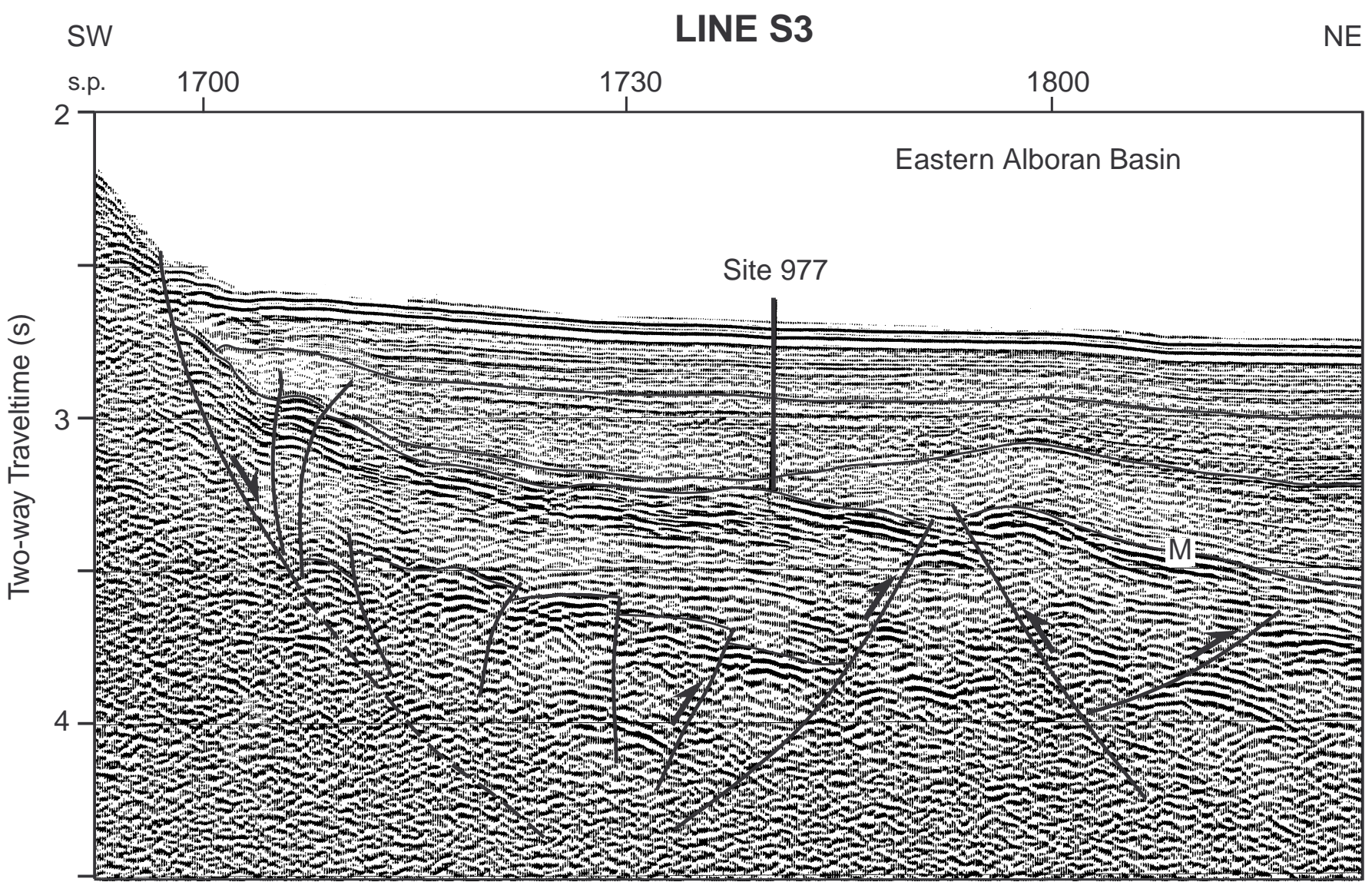

Figure 6. Portion of the line S3 showing the structure of the southern part of the Eastern Alboran Basin (M = M-reflector). A strike-slip fault next to the Yusuf Ridge seems to have been active until recent times and some faults forming a negative flower structure seem to reactivate pre-M-reflector structures. Two main unconformities have formed within the Pliocene to Holocene sediments that were drilled at Site 977, related to strike-slip tectonism. s.p. $=$ shotpoints. Location in Figure 2.

in the South Alboran Basin coincident with Ray 36 profile, which crosses the basin oblique to its trend, in a north-south orientation (Fig. 11). In this section, the basin sedimentary fill thickens southward toward the depocenter of the basin. The oldest sediments drilled at this site were of late Pliocene age (Fig. 3), although the borehole was stopped a few tens of meters before reaching a major angular unconformity seen in the seismic profile. Based on the data acquired by Leg 161, this unconformity has been proposed to correspond to the same erosional M-unconformity cored at Sites 977 and 978 in the Eastern Alboran Basin (Comas, Zahn, Klaus, et al., 1996). In the Ray 36 profile, the unconformity is marked by the progressive truncation of underlying reflections toward the Alboran Ridge. A south-verging monocline developed above a thrust fault in the basement, and the syntectonic deposition of Pliocene to Holocene sedimentary sequences is evidenced by the growth strata on the southern limb of the monocline. This monocline probably correlates with the fold-like structure described by Watts et al. (1993) in the Conrad 825 profile located to the west of profile Ray 36. In Conrad 824 profile, a possible strikeslip fault appears to bound the basin to the north, and deformation of the sedimentary fill could be related to a flower-like structure in the basement (Fig. 12).

\section{DISCUSSION AND TECTONIC IMPLICATIONS}

The active tectonic setting of the Alboran Basin is characterized by a variety of structures, of which the most important are the strikeslip fault systems. It has been proposed that strike-slip faulting was active since at least late Tortonian times (Comas et al., 1992; Bourgois et al., 1992; Woodside and Maldonado, 1992) during which the Alboran Basin was broken into sub-basins divided by transverse volcanic ridges. Active volcanism was coeval with the strike-slip tectonism as evidenced by the ages obtained in samples of shoshonitic lavas (4.5-9 Ma.) and alkali basalts (1.5-6 Ma; Bellon et al., 1983; Hernández et al., 1987; de Larouzière et al.,1988; Montenat et al., 1992). Two sets of conjugate strike-slip fault systems are identified in the Alboran Basin that have been attributed to a pure shear deformation mechanism related to a north-south to northwest-southeast convergence of Iberia and Africa (Vegas, 1992). Preserved lower Miocene- to Pliocene-age marine sediments outcropping in the Betic and Rif Cordilleras (Montenat and Ott d'Estevou, 1996; Meghraoui et al., 1996) indicate uplift along the margins of the subsiding Alboran Basin since late Tortonian times.

Since Pliocene to Holocene times, the Eastern Alboran Basin has been subsiding within an open marine environment, and is being filled by pelagic sediments between two segments of the conjugate strike-slip fault system, the left lateral fault system at the Iberian side and the right lateral Yusuf Fault system in the African side. In the seismic profile across the basin, flower structures are recognized at both sides of the Al-Mansour Seamount. In addition, in the northern side of the basin (Fig. 2), an east-west-trending deep seismic profile (ESCI-Alb 2, Comas et al., 1997) shows dominantly east-dipping extensional faults, locally causing westward tilting of a basement block resulting in a bend of the upper sedimentary units, and suggesting that the extensional faults have been active since at least Pliocene to Holocene times. This structural geometry indicates that the Eastern Alb- 


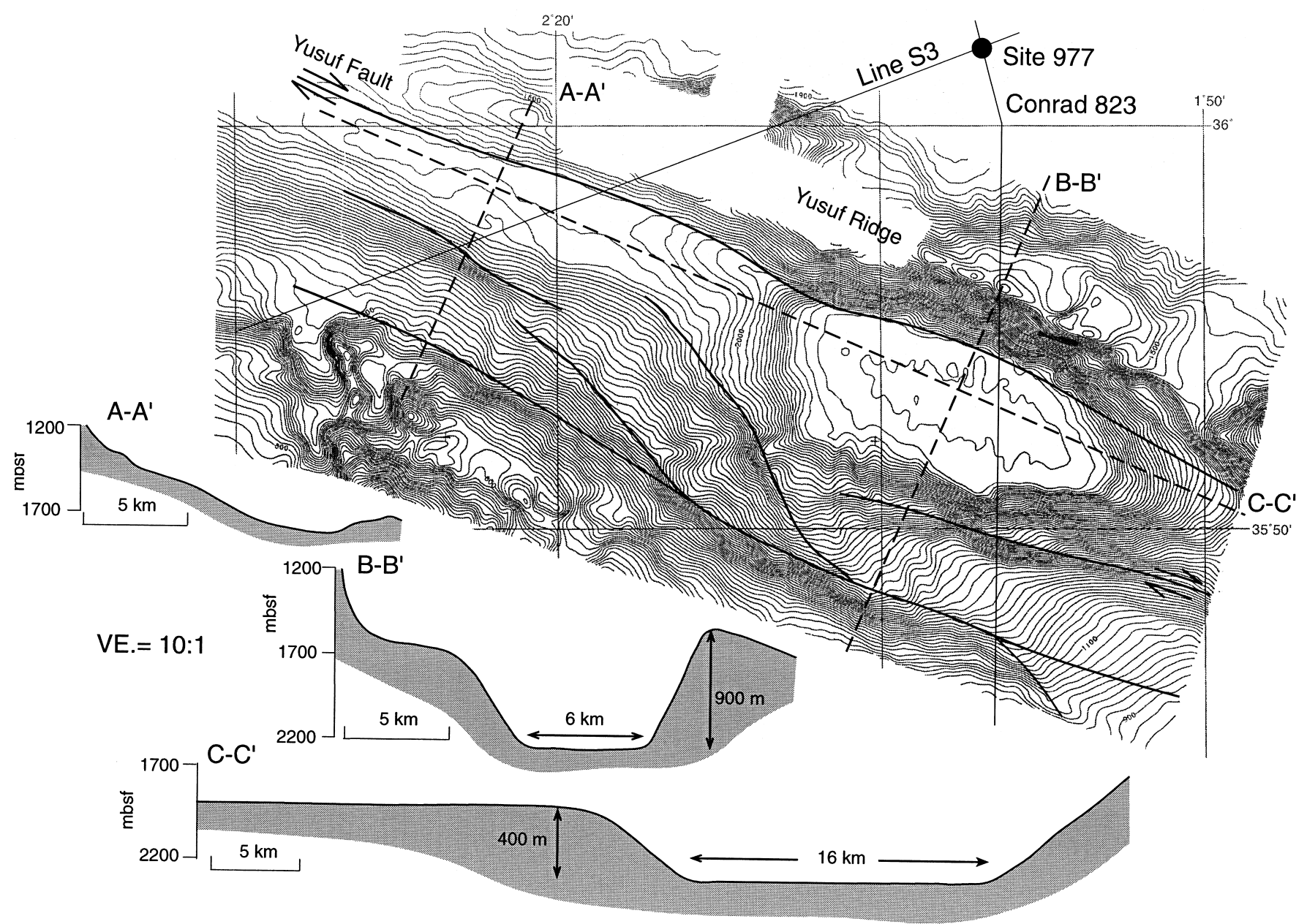

Figure 7. Detailed bathymetry of the Yusuf Basin developed next to the Yusuf right-lateral strike-slip fault. Bathymetry data is from Pfannenstiel (1975). Dimensions of the basin are illustrated by two topographic profiles perpendicular to the fault strike (A-A', B-B') and a profile parallel to it (C-C'). Note that the profiles have a 10:1 vertical exaggeration. Thicker lines correspond to faults that have been drawn based on seismic profiles (thin black lines) and seafloor morphology.

oran Basin is subsiding because of an east-west extension within a triangular block bounded by conjugate strike-slip faults. The tectonic configuration and triangle geometry of the block within which the Eastern Alboran Basin is evolving resembles that of the tectonic scape process that has been described as occurring along irregular convergent zones such as the Anatolian block in Turkey (Sylvester, 1988).

Previous studies proposed that the Yusuf Basin evolved during Pliocene-Quaternary times as a half-graben bounded by a southwestdipping escarpment related to the Yusuf strike-slip fault (e.g., Mauffret et al., 1987). These authors also suggested a horizontal displacement for the Yusuf Fault of 30-35 km based on the distribution of magnetic anomalies and the basin morphology. The map view distribution of faults of the Yusuf Fault system is similar to that of the right lateral pure shear model described by Sylvester (1988). In this scenario, the Yusuf Basin would be evolving at a right stepover between two en echelon, slightly nonparallel strike-slip faults. In cross section, and within the sedimentary sequences in the basin, the thin preM sedimentary package exhibits closely spaced faults, whereas post$M$ sediments of the basin walls are deformed by listric extensional faults. Listric faulting results in sliding of hanging wall material downslope toward the trough, indicating gravity sliding as a result of slope instability.

In well-known strike-slip basins on land, sediments commonly show an overlapping arrangement, younging in the slip direction to- ward the depocenter, while sediment dispersal occurs in the opposite sense (Steel and Gloppen, 1980; Nilsen and McLaughlin, 1985). This sedimentary arrangement has been interpreted to be caused by the depocenter migrating in the direction opposite to that of strike-slip movement of the basin (Nilsen and McLaughlin, 1985; Sylvester, 1988). Similarly, the fact that the S3 profile (Fig. 6) shows sediments dipping northeast, whereas the north-south section (Fig. 7) shows a symmetric ponded-type arrangement, may indicate syntectonic sedimentation dipping eastward and migration westward of the depocenter (in a dextral strike-slip). The difference in geometry between the cross sections, however, may be the result of the orientation and position of the lines relative to the basin bounding faults. In analog models (McClay and Dooley, 1995; Dooley and McClay, in press), the pull-apart basin narrows and turns asymmetric as one sidewall fault zone becomes dominant and the other dies out. In these models the prekinematic and synkinematic sediments dip toward the dominant fault similar to the S3 profile in the Yusuf Basin.

The topographic elongation of the Alboran Ridge together with land data from the eastern Betics and Rif zone led de Larouzière et al. (1988) to propose that the ridge formed within a sinistral strike-slip fault system termed "Trans-Alboran shear zone." The ridge is a faultbounded relatively recent structure (post-Miocene; Comas et al., 1992, Woodside and Maldonado, 1992) that has been interpreted as a compressional structure bound at both sides by reverse faults (Woodside and Maldonado, 1992; Bourgois et al., 1992). However, Comas 


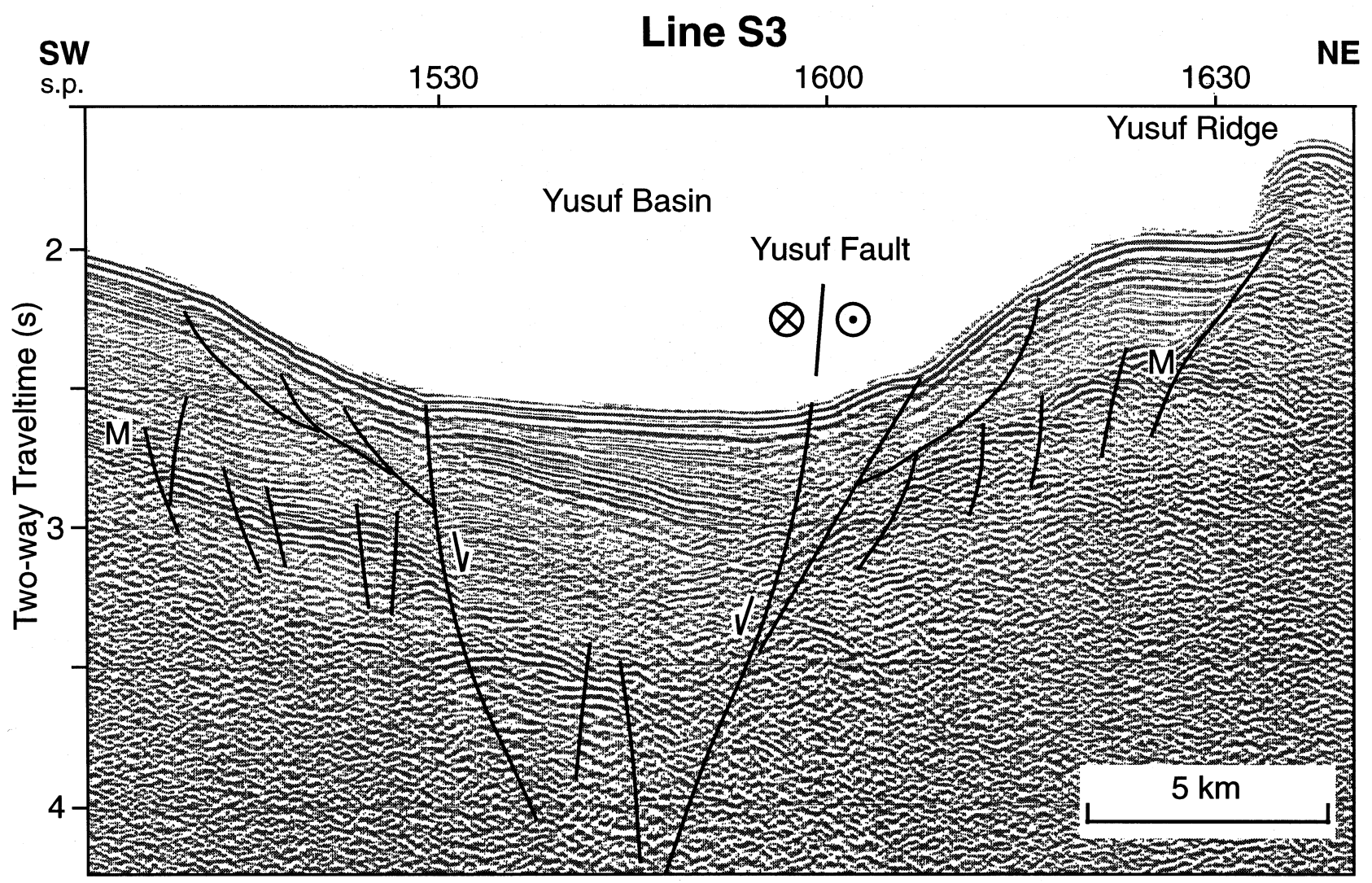

Figure 8. Interpretation of the structure of part of Line 3S through the Yusuf Basin. The M-reflector (M) is interpreted based on the seismic character of sedimentary packages. The active Yusuf Fault at the northern border of the basin is evidenced by the fan-shaped uppermost sediments. s.p. $=$ shotpoints. Location in Figure 2. Circles indicate relative movement of the two sides of the fault: circle with dot $=$ out of page; circle with $\times=$ into the page.

et al. (1992) propose the existence of a normal fault at the northern flank. Watts et al. (1993), however, propose that the data are inconclusive and that the structure could correspond to a strike-slip fault as previously proposed by de Larouzière et al. (1988). The data presented in this paper indicate that a master strike-slip fault exists at the northern slope of the Alboran Ridge, and the relatively recent strikeslip basin that appears in the Alboran Channel is related to this fault.

Both Woodside and Maldonado (1992) and Watts et al. (1993) found compressional structures in the southern flank of the ridge. A fold-like structure described by Watts et al. (1993) and a northwestdipping reverse fault (Woodside and Maldonado, 1992) are coeval structures in the edge of the South Alboran Basin. In the Conrad 824 profile the basin evolves next to a strike-slip fault developed near the flank of the Alboran Ridge. A northwest-dipping reverse fault coincides with the Jebha sinistral strike-slip fault inland (Morel and Meghraoui, 1996; Meghraoui et al., 1996). A south-verging monocline imaged above a reverse fault in the basement in Ray 36 profile with associated deposition of Pliocene to Holocene sedimentary sequence correlates with the fold-like structure described by Watts et al. (1993) in the Conrad 825 profile, located slightly west of line Ray 36.

\section{CONCLUSIONS}

In the eastern part of the Alboran Sea, the Alboran Channel, Eastern Alboran, Yusuf, and South Alboran Basins constitute very good examples of strike-slip basins developed in an open marine environment. The basins evolved during Pliocene to Holocene times as active subsiding zones related to strike-slip tectonism, and are commonly bound by elongated bathymetric highs of volcanic origin next to which the major strike-slip faults appear. Major northeast- to southwest-trending strike-slip faults have a left lateral sense of movement and faults trending west northwest-east southeast have right lateral sense of movement. In cross-section, the most common structures in these basins are negative flower structures with syndepositional unconformities within the sedimentary fill. The flower structure is formed by coeval multi-strand faults that exhibit vertical throws with apparent reverse and normal components. Locally, faultrelated folds give rise to growth strata indicating continuous fault activity and sedimentation during the Pliocene to Holocene times.

The triangular-shaped Eastern Alboran Basin is forming within two strands of a conjugate strike-slip fault system, which are left lateral in the Iberian side and right lateral in the African side. The basin exhibits two major flower structures in cross-section, which are developing at both sides of the Al-Mansour Seamount. Locally, minor faults within the flower structure reactivate previous possible Miocene faults.

The Yusuf Basin exhibits a 16-km-long by 9-km-wide active depocenter that is subsiding at a right stepover of the Yusuf right lateral strike-slip fault system. In cross section, active tectonic subsidence occurs between two main subvertical faults. The Yusuf Fault exhibits a vertical throw of more than $2 \mathrm{~km}$ and related syntectonic sedimentation has been ongoing at least since the late Miocene. In a cross section oblique to the elongation of the basin the sedimentary fill forms a north-eastward-thickening wedge of syntectonic sediments of Pliocene to Holocene age. The steep basin sidewalls are commonly formed by basinward-dipping Pliocene to Holocene sediments deformed by listric extensional faults that seem to be caused by gravitational instability.

In the South Alboran Basin, evidence of syntectonic sedimentation during the Pliocene to Holocene is the formation of growth strata 
CONRAD 823

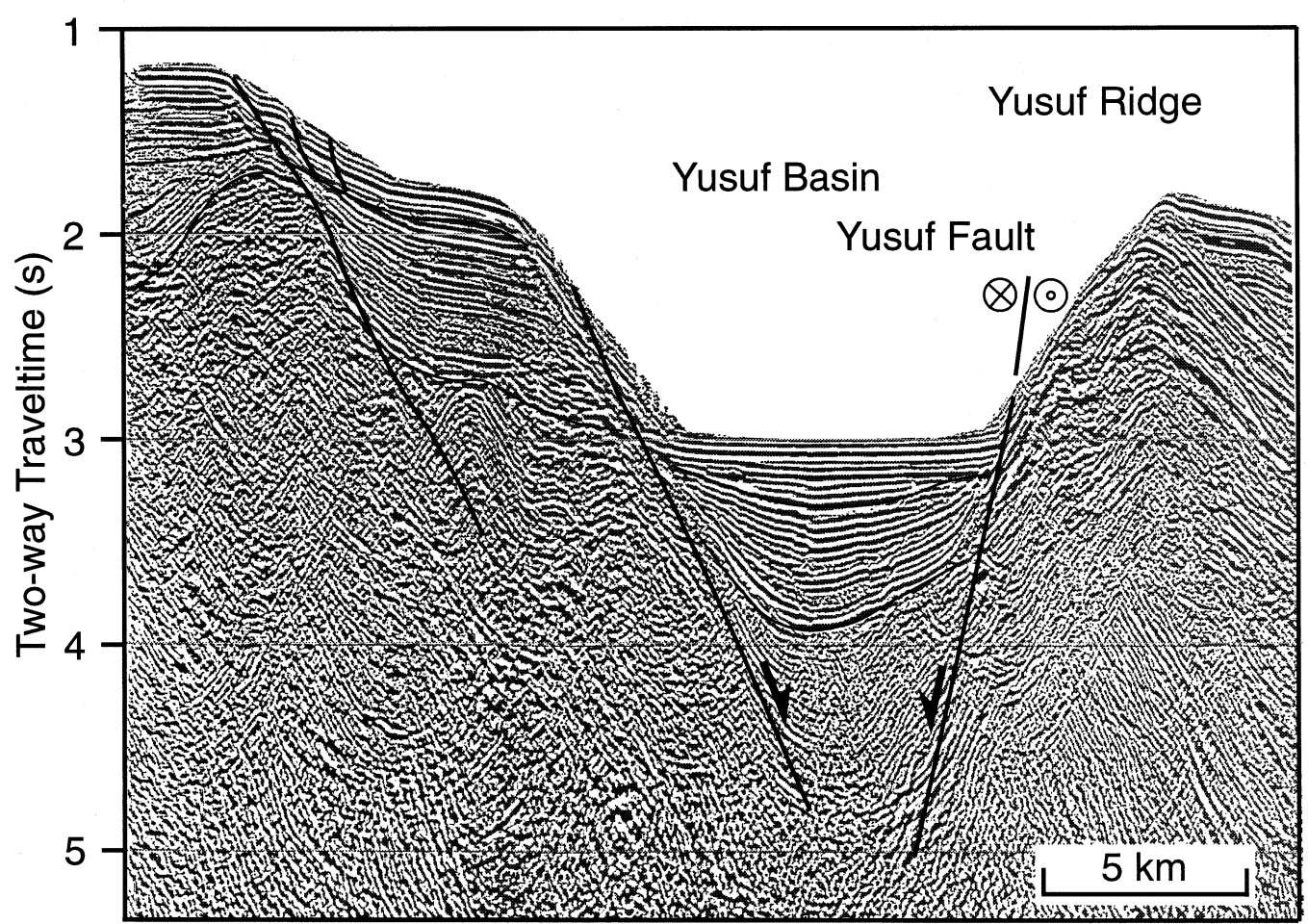

Figure 9. Interpretation of part of Conrad 823 profile, which indicates a pounded geometry of the Yusuf Basin subsiding between two major strike-slip faults. Location in Figure 2.

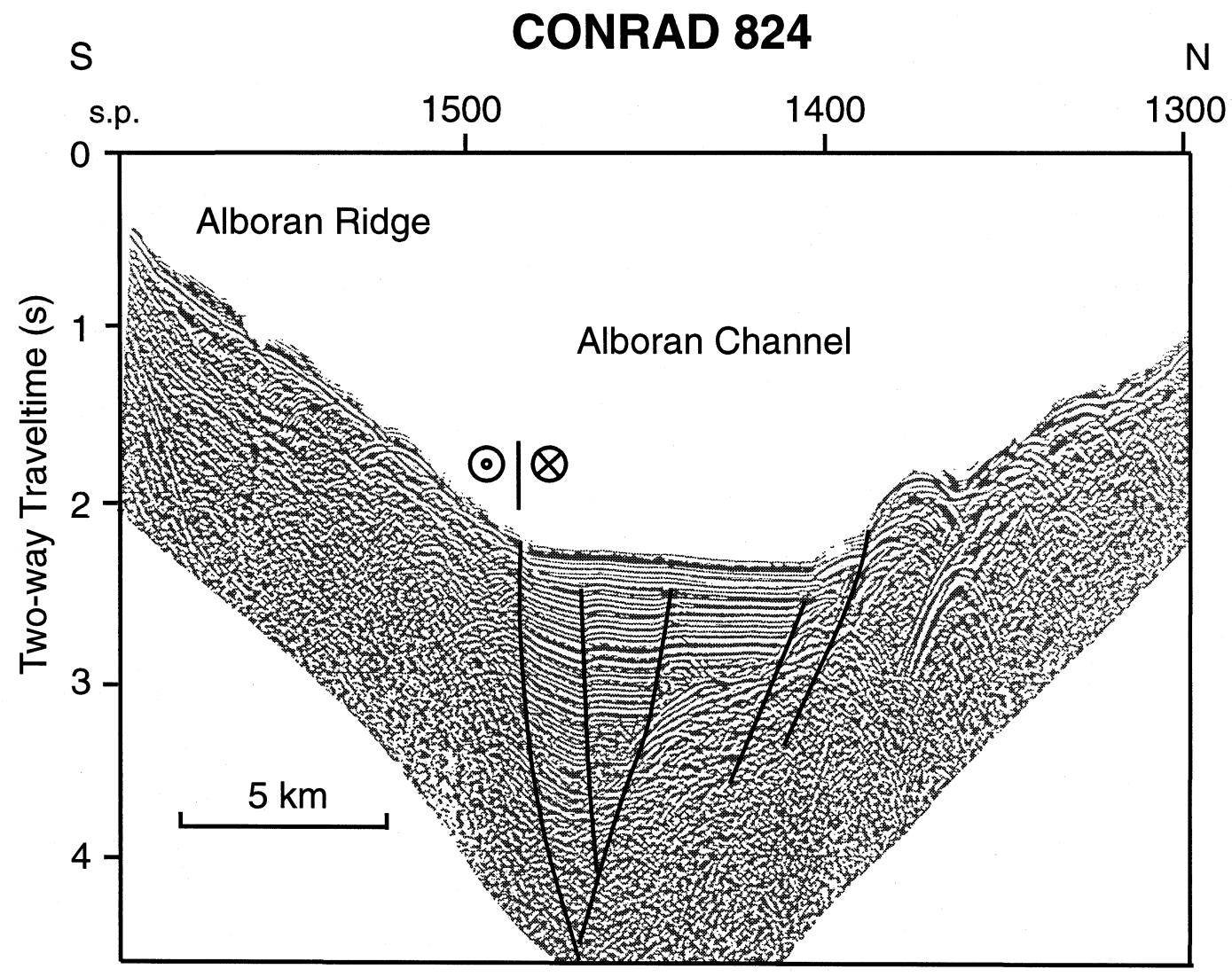

Figure 10. Interpretation of part of Conrad 82 profile across the Alboran Channel showing a strike-slip master fault at the base of the northern slope of the Alboran Ridge. s.p. = shotpoints. Location in Figure 2. 


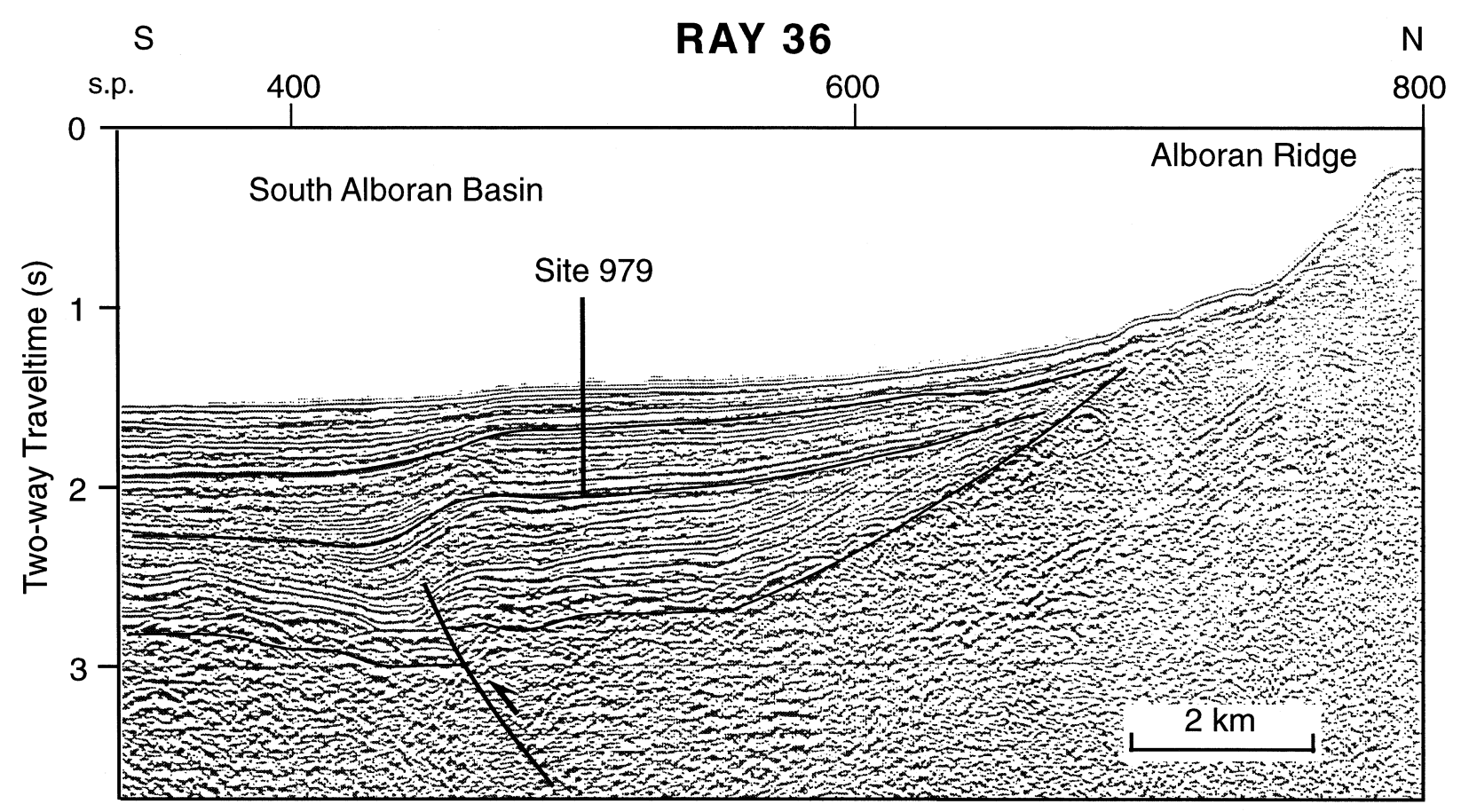

Figure 11. Interpretation of part of Ray 36 profile across the northern side of the South Alboran Basin showing the interpreted distribution of main unconformities. s.p. $=$ shotpoints.

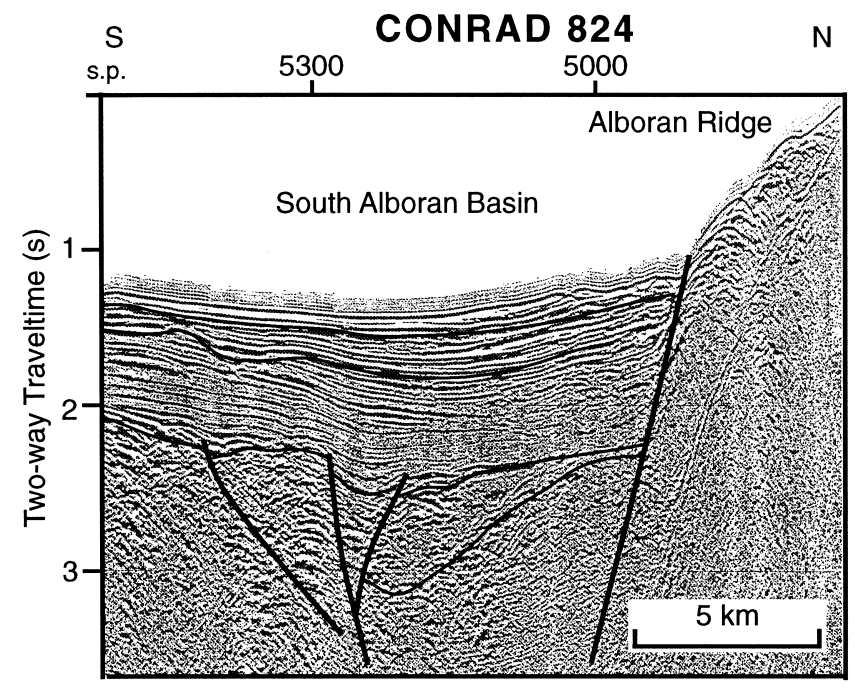

Figure 12. Interpretation of part of Conrad 824 profile across the South Alboran Basin showing strike-slip structures in the northern part of the South Alboran Basin and a possible strike-slip master fault at the base of the southern slope of the Alboran Ridge. s.p. $=$ shotpoints. Location in Figure 2.

geometries in the sedimentary fill, related to a south-dipping monocline that forms above a north-dipping thrust in the basement. In the Alboran Channel, a basin develops next to a master strike-slip fault at the base of the Alboran Ridge. The basin exhibits the narrow, deep and asymmetric morphology of strike-slip basins.

\section{ACKNOWLEDGMENTS}

The author is indebted to ODP for the seismic data provided for this research. M. Comas provided the rest of the data, and is thanked for her support, encouragement, and endless discussions on the geology of Alboran, which made possible this research. T. Dooley and A. Mauffret are thanked for their constructive reviews that helped to improve the manuscript. Founding from the Spanish commission CICYT, project AMB95-1557 is acknowledged.

\section{REFERENCES}

Albarello, D., Mantovani, E., Babbucci, D., and Tamburelli, C., 1995. AfricaEurasia kinematics: main constraints and uncertainties. Tectonophysics, 243:25-36.

Argus, D.F., Gordon, R.G., DeMets, C., and Stein, S., 1989. Closure of Africa-Eurasia-North America Plate motion circuit and tectonics of the Gloria fault. J. Geophys. Res., 94:5585-5602.

Auzende, J.M., Rehault, J.-P., Pastouret, L., Szep, B., and Olivet, J.-L., 1975. Les basins sèdimentaires de la mer d'Alboran. Bull. Soc. Geol. Fr., Ser. 7, XVII, 1:98-107.

Balanyá, J.C., 1991. Estructura del Dominio de Alborán en la parte norte del arco de Gibraltar [Ph.D. thesis]. Univ. Granada.

Balanyá, J.C., and García-Dueñas, V., 1987. Les directions structurales dans le Domaine d'Alboran de part et d'autre du Détroit de Gibraltar. C. $R$. Acad. Sci. Ser. 2, 304:929-932.

Banda, E., and Ansorge, J., 1980. Crustal structure under the central and eastern part of the Betic Cordillera. Geophys. J. R. Astron. Soc., 63:515-532.

Banda, E., Gallart, J., García-Dueñas, V., Danobeitia, J., and Makris, J., 1993. Lateral variation of the crust in the Iberia Peninsula: new evidence for the Betic Cordillera. Tectonophysics, 221:53-66.

Bellon, H., Bordet, P., and Montenat, C., 1983. Le magmatisme néogène des Cordillères bétiques (Espagne): cronologie et principaux caractères géochimiques. Bull. Soc. Geol. Fr., Ser. 7, 25:205-218.

Bourgois, J., Mauffret, A., Ammar, A., and Demnati, N.A., 1992. Multichannel seismic data imaging of inversion tectonics of the Alboran Ridge (Western Mediterranean Sea). Geo-Mar. Lett., 12:117-122.

Buforn, E., Sanz de Galdeano, C., and Udías, A., 1995. Seismotectonics of the Ibero-Maghrebian region. Tectonophysics, 248:247-261.

Comas, M.C., Bourgeois, J., Boulègue, J., Fernandez-Soler, J.M., de la Linde, J., and Soto, J.I., in press. Preliminary results of the Cyanalboran cruise: dives of the submersible CYANA in the Alboran Sea. Terra Nova.

Comas, M.C., Dañobeitia, J.J., Alvarez-Marrón, J., and Soto, J.I., 1997. Crustal reflections and structure in the Alboran Basin: preliminary results of the ESCI-Alboran Survey. Rev. Soc. Geol. Esp., 8, 1995:529-542. 
Comas, M.C., García-Dueñas, V., and Jurado, M.J., 1992. Neogene tectonic evolution of the Alboran Basin from MCS data. Geo-Mar. Lett., 12:157164.

Comas, M.C., Zahn, R., Klaus, A., et al., 1996. Proc. ODP, Init. Repts., 161: College Station, TX (Ocean Drilling Program).

de Larouzière, F.D., Bolze, J., Bordet, P., Hernandez, J., Montenat, C., and Ott d'Estevou, P., 1988. The Betic segment of the lithospheric trans-Alboran shear zone during the Late Miocene. Tectonophysics, 152:41-52.

Demets, C., Gordon, R.G., Argus, D.F., and Stein, S., 1990. Current plate motions. Geophys. J. Int., 101:425-478.

Dewey, J.F., Helman, M.L., Turco, E., Hutton, D.H.W., and Knott, S.D., 1989. Kinematics of the western Mediterranean. In Coward, M.P., Dietrich, D., and Park, R.G. (Eds.), Conference on Alpine Tectonics. Geol. Soc. Spec. Publ. London, 45:265-283.

Dillon, W.P., Robb, J.M., Greene, H.G., and Lucena, J.C., 1980. Evolution of the continental margin of Southern Spain and the Alboran Sea. Mar. Geol., 36:205-226.

Dooley, T., and McClay, K.R., 1997. Analog modelling of pull-apart basins. $A A P G, 11: 1804-1826$.

García-Dueñas, V., Balanyá, J.C., and Martínez-Martínez, J.M., 1992. Miocene extensional detachments in the outcropping basement of the northern Alboran basin (Betics) and their tectonic implications. Geo-Mar. Lett., 12:88-95.

Gensous, B., Tesson, M., and Winnock, E., 1986. La marge meridionale de la Mer d'Alboran: caracteres structuro-sedimentaires et évolution recente. Mar. Geol., 72:341-370.

Giermann, G., Pfannenstiel, M., and Wimmenauer, W., 1968. Relation entre morphologie, tectonique et volcanisme en mer d'Alboran (Mediterranée occidentale): resultats preliminaires de la campagne Jean-Charcot (1967). C. R. Somm. Seances Soc. Geol. Fr., 4:116-118.

Hatzfeld, D., 1978. Etude sismo-tectonique de la zone de collision iberomaghrébine [Thèse Sci.]. I.R.I.G.M., Univ.Grenoble.

Hernandez, J., de Larouzière, F.D., Bolze, J., and Bordet, P., 1987. Le magmatisme néogène bético-rifain et le couloir de décrochement trans-Alboran. Bull. Soc. Geol. Fr., 3:257-267.

IOC-UNESCO, 1981. International bathymetric chart of the Mediterranean (scale 1:1,000,000). Min. Def., Leningrad, sheet 6.

Jurado, M.J., and Comas, M.C., 1992. Well log interpretation and seismic character of the Cenozoic sequence in the Northern Alboran Sea. GeoMar. Lett., 12:129-136.

Kazakov, O.V., Mitulav, S.N., and Shlezinger, A.Y., 1983. The structure of the sediment cover in the Alboran Sea according to seismoacoustic profiling data. Int. Geol. Rev., 25:1375-1385.

Keller, J.V.A., Hall, S.H., Dart, C.J., and McClay, K.R., 1995. The geometry and evolution of a transpressional strike-slip system: the Carboneras fault, SE Spain. J. Geol. Soc. London, 152:339-352.

Klaus, A., and Shipboard Scientific Party, 1996. Underway geophysics. In Comas, M.C., Zahn, R., Klaus, A., et al., Proc. ODP, Init. Repts., 161: College Station, TX (Ocean Drilling Program), 51-52.

Mauffret, A., El-Robrini, M., and Gennesseaux, M., 1987. Indice de la compression récente en mer Méditerranée: un bassin losangique sur la marge nor-algérienne. Bull. Soc. Geol. Fr., 8:1195-1206.

Mauffret, A., Maldonado, A., and Campillo, A.C., 1992. Tectonic framework of the Eastern Alboran and Western Algerian Basins, Western Mediterranean. Geo-Mar. Lett., 12:104-110.

McClay, K.R., and Dooley, T., 1995. Analogue models of pull-apart basins. Geology, 23:711-714

Meghraoui, M., Morel, J.L., Andrieux, J., and Dahmani, M., 1996. Tectonique plio-quaternaire de la chaîne tello-rifaine et de la mer d'Alboran: une zone complexe de convergence continent-continent. Bull. Soc. Geol. Fr., 167:141-157.

Montenat, C., 1990. Les bassins néogènes du domaine betique oriental (Espagne). Tectonique et sédimentation dans un couloir de décrochement. Première partie: étude régionale. Doc. Trav., IGAL, Paris, 12-13.
Montenat, C., and Ott d'Estevou, P.O., 1996. Late Neogene basins in the Eastern Betics. In Friend, P.F., and Dabrio, C.J. (Eds.), Tertiary Basins of Spain, the Stratigraphic Record of Crustal Kinematics: London (Cambridge Univ. Press).

Montenat, C., Ott d'Estevou, P., De Larouzière, F.D., and Bedu, P., 1992. Originalité géodynamique des bassins Néogène du domaine Bétique orientale. IGAL, Notes Mem., 1-21:11-49.

Morel, J.L., and Meghraoui, M., 1996. Gorringe-Alboran-Tell tectonic zone: a transpression system along the Africa-Eurasia plate boundary. Geology, 24:755-758.

Nilsen, T.H., and McLaughlin, R.J., 1985. Comparison of tectonic framework and depositional patterns of the Hornelen strike-slip basin of Norway and the Ridge and Little Sulfur Creek strike-slip basins of California. In Biddle, K.T., and Christie-Blick, N. (Eds.), Strike-Slip Deformation, Basin Formation and Sedimentation. Spec. Publ.-Soc. Econ. Paleontol. Mineral., 37:79-103.

Olivet, J.L., Bonnin, J., Beuzart, P., and Auzende, J.M., 1984. Cinématique de l'Atlantique nord et central. Publ. Cent. Natl Exploit. Oceans, Rapp. Sci. Tech., 54:108-112.

Pastouret, L., Olivet, J.L., Auzende, J.M., and Rehault, J.P., 1975. Remarques complementaires sur le Neogene de la Mer d'Alboran. Bull. Soc. Geol. Fr., 17:1168-1171.

Pfannenstiel, M., 1975. Die Enstehung des Alboranmeeres aus dem alten Alboranlan Ein Beitrag Zur Geotektonic des Westlichen. Mem. Inst. Ocean, Fond. Albert 1er, Pr. Monaco, 8.

Platt, J.P., Soto, J.I., Comas, M.C., and Leg 161 Shipboard Scientists, 1996. Decompression and high-temperature-low-pressure metamorphism in the exhumed floor of an extensional basin, Alboran Sea, Western Mediterranean. Geology, 24:447-450.

Polyak, B.G., Fernàndez, M., Khutorsky, M.D., Soto, J.I., Basov, I.A., Comas, M.C., Khain, V.Y., Alonso, B., Agapova, G.V., Mazurova, I.S., Negredo, A., Tochitsky, V.O., de la Linde, J., Bogdanov, N.A., and Banda, E., 1996. Heat flow in the Alboran Sea (the Western Mediterranean). Tectonophysics, 263:191-218.

Ryan, W.B.F., Hsü, K.J., et al., 1973. Init. Repts. DSDP, 13 (Pts. 1 and 2): Washington (U.S. Govt. Printing Office).

Srivastava, S.P., Roest, W.R., Kovacs, L.C., Oakey, G., Lévesque, S., Verhoef, J., and Macnab, R., 1990. Motion of Iberia since the Late Jurassic: results from detailed aeromagnetic measurements in the Newfoundland Basin. Tectonophysics, 184:229-260.

Steel, R.J., and Gloppen T.G., 1980. Late Caledonian (Devonian) basin formation, western Norway: signs of strike-slip tectonics during infilling. In Ballance, P.F., and Reading, H.G. (Eds.), Sedimentation in Oblique-Slip Mobile Zones. Spec. Publ. Int. Assoc. Sedimentol., 4:79-103.

Sylvester, A.G., 1988. Strike-slip faults. Geol. Soc. Am. Bull., 100:16661703.

Torné, M., and Banda, E., 1992. Crustal thinning from the Betic Cordillera to the Alboran Sea. Geo-Mar. Lett., 12:76-81.

Vegas, R., 1992. Sobre el tipo de deformación distribuida en el contacto entre Africa y la Península Ibérica. In Osete, M.L., and Calvo, M. (Eds.), Fisica de la Tierra: Paleomagnetismo y Tectónica en las Cordilleras Beticas: Madrid (Editorial Complutense), 4:41-56.

Watts, A.B., Platt, J.P., and Buhl, P., 1993. Tectonic evolution of the Alboran Sea Basin. Basin Res., 5:153-177.

Woodside, J.M., and Maldonado, A., 1992. Styles of compressional neotectonics in the Eastern Alboran Sea. Geo-Mar. Lett., 12:111-116.

Date of initial receipt: 7 May 1997

Date of acceptance: 6 November 1997

Ms 161SR-224 